\title{
Legal object commentary: anti-slavery medallion
}

\author{
OWAIN JOHNSTONE ${ }^{1}$
}

Centre for Socio-Legal Studies, Oxford University

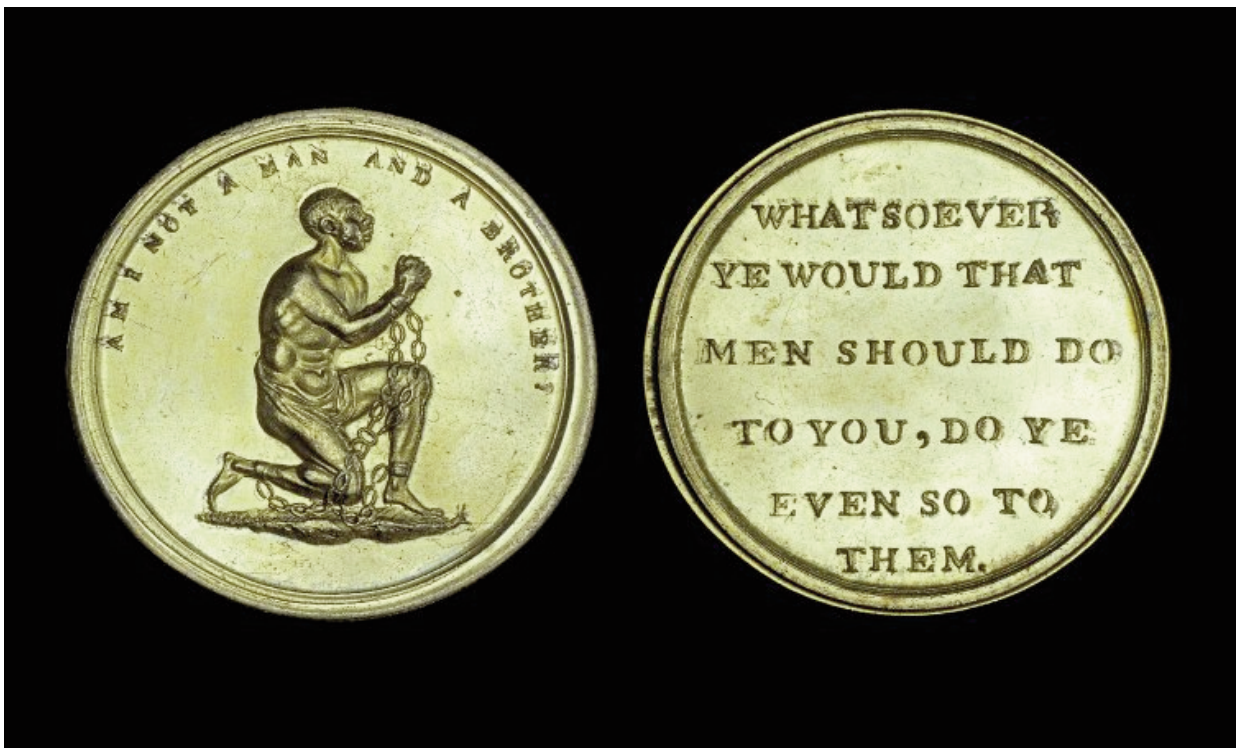

Anti-slavery medallion

(C) Trustees of the British Museum $\dagger$

\begin{abstract}
This anti-slavery medallion was cast in 1787, based on the symbol of the London Society for the Suppression of the Slave Trade. It was a key object and image within the movement to abolish the slave trade in Britain. The medallion conveys a particular understanding of the slave trade as a social problem (such as assuming the vulnerability and passivity of the slave). Consequently, the medallion speaks to recent literature on the social construction of social problems. That literature, however, has tended to focus on the role of discourse in problem construction - rather than material objects like the medallion. This article interrogates the nature of the medallion as a material problem representation, bringing it into dialogue with discursive representations of a related contemporary issue: human trafficking. The article suggests ways in which the medallion challenges and develops those discursive representations. It concludes that the material dimension of the representation - and construction - of social problems is easily overlooked despite its significance, and that it merits further investigation.
\end{abstract}

Keywords: slavery; abolition; human trafficking; social problems; materiality.

$\dagger \quad<$ www.britishmuseum.org/research/collection_online/collection_object_details.aspx?assetId= 210453001\&objectId=949185\&partId=1>

$1 \mathrm{PhD}$ candidate at the Centre for Socio-Legal Studies, Oxford University, owain.johnstone@law.ox.ac.uk. Thank you to Amanda Perry-Kessaris and to one anonymous reviewer for very helpful comments. 


\section{Introduction}

7 his medallion is approximately $3 \mathrm{~cm}$ across and is struck in bronze. It shows the figure of a kneeling slave in profile, bound in chains, with his hands raised in supplication. The caption below the man reads: 'Am I not a man and a brother?' The reverse of the medallion contains a second text, which reads: 'Whatsoever ye would that men should do to you, do ye even so to them.' The text is from the King James Bible, Matthew 7:12.

The medallion was cast in 1787, based on the design for the official symbol of the London Society for the Suppression of the Slave Trade - the leading English abolitionist group that was founded in that year. ${ }^{2}$ The precise origins of the medallion are not completely clear, but it seems that Josiah Wedgwood - the famous pottery maker - at least advised on the design and may well have been responsible for manufacturing the first version. ${ }^{3}$

I was drawn to the medallion because it constitutes a representation of a social problem - the slave trade. My research deals with representations of a related, contemporary social problem - human trafficking. I am interested in particular in tracing the changing construction of 'human trafficking's in the UK and identifying the contribution that the British state has made to that construction over the 2000-2015 period. I focus in particular on the way in which the state has used certain tools - legislation, policy statements, administrative rules - to shape the way in which trafficking is constructed. In this paper I consider various ways in which the medallion speaks to my research.

The paper is divided into six parts. First, I discuss some core assumptions from the literature on the social construction of social problems, which is the main literature to which my research contributes. I show how the medallion-as-problem-representation relates to that literature. Second, I give a brief overview of the history of the medallion. Then, in the main three parts of the article, I use the medallion as an interlocutor to interrogate three different kinds of representations of human trafficking: a contemporary anti-trafficking medallion that deliberately evokes the medallion discussed here; recent pronouncements on trafficking by British politicians; and a recent piece of British legislation on human trafficking - the Modern Slavery Act 2015. In the final section, I offer some concluding thoughts.

\section{The social construction of social problems}

The core assumption in the literature on the social construction of social problems is that there are no objectively verifiable criteria by which something should be labelled a social problem. We should therefore study the process of problem construction rather than problems themselves. Consequently, scholars study 'claims' made as to whether particular conditions constitute a problem or not, and how those claims are responded to. ${ }^{5}$

Exactly what a 'claim' is depends on the context - but it is some kind of representation of a set of circumstances. It could be an explicit statement by a charity to the effect that temporary homelessness (for example) is a problem that needs to be addressed. Or it could be something more implicit or symbolic, like a photograph of a

2 Robin Reilly, Josiah Wedgwood, 1730-1795 (Macmillan 1992) 286; John R Oldfield, Popular Politics and British AntiSlavery: The Mobilisation of Public Opinion against the Slave Trade 1787-1807 (Routledge 2012) 156.

3 Oldfield (n 2) 156; Leo d'Anjou, Social Movements and Cultural Change: The First Abolition Campaign Revisited (Transaction Publishers 1996) 163.

4 I have placed scare quotes around 'human trafficking' here in order to emphasise that I am interested in the nature of trafficking as a constructed object and that I do not presuppose the objectively verifiable existence or any particular characteristics of trafficking.

5 Malcolm Spector and John I Kitsuse, Constructing Social Problems (Transaction Publishers 2001) 76. 
deforested area published in a newspaper - where the claim is that deforestation is a problem. The medallion constitutes a claim made by the abolitionists about the 'social problem' of slavery.

Different claims have different characteristics. The deforestation photograph is not as clear as the charity's statement. It does not specify what is thought to be the cause of the problem (perhaps criminal activity, lax regulation, or development policies). Nor does it specify what should be done about it. The charity's statement probably does both (although it does not have to, of course). But the photograph has certain advantages: it is easy to grasp, emotive and immediate; it is widely distributed (if published in a national newspaper); and it can appeal to a wider audience precisely because it is less specific people who have divergent opinions about the causes of and solutions to deforestation can still agree that deforestation is a problem.

Different kinds of claims may be suited to particular audiences, channels of distribution and problems. Deforestation and homelessness are both problems that can be represented in photographs; voter apathy is much harder to depict visually.

These ideas speak to the article by Bruno Latour cited by Amanda Perry-Kessaris in the introduction to this special issue. ${ }^{6}$ In that article, Latour argues that a focus on objects or things (Dingpolitik) can offer a productive perspective on political activity, broadly understood. Instead of concentrating on process and procedure (elections, debates, legislative drafting etc.), Latour suggests we should focus on objects or issues of shared concern - the things that bring us together to make collective decisions, rather than the ways in which we come together to discuss them. A focus on social problems does exactly that. Beginning with a particular issue, we might want to ask what claims are made about it, by whom, for which audiences, within which arenas.

Latour argues that this object-focus can bring together two senses of 'representation': the political - certain people come to represent sections of the population in government, for example; and the scientific - people represent (describe, explain) phenomena in the world to one another (as I am doing in this article). The former kind of representation is evaluated according to its legitimacy, the latter according to its accuracy.

A claim about a social problem is primarily a representation of the second type, implying or asserting that the world is a certain way. But claims are made by and within arenas constituted by representations of the first kind, which, Latour suggests, 'draw [ a sort of place, sometimes a circle, which might be called an assembly, a gathering, a meeting, a council' (which could be a national parliament, but might also be a laboratory, or a newspaper office). ${ }^{7}$

Both kinds of representations involve what Latour terms 'representation technolog[ies]'. 8 These might include election procedures and voting booths, perhaps, in the first kind, or microscopes and statistics, for example, in the latter.

In this commentary, I discuss the medallion as a kind of representation technology, placing it in dialogue with three other kinds: a contemporary anti-trafficking medallion, recent discussions of human trafficking by politicians, and recent legislation on human trafficking in the UK. I consider the particular characteristics of each and how the medallion speaks to them. I particularly emphasise the materiality of the medallion.

6 Bruno Latour, 'From Realpolitik to Dingpolitik' in Bruno Latour and Peter Weibel (eds), Making Things Public: Atmospheres of Democracy (MIT Press 2005).

7 Ibid 6.

8 Ibid 24. 


\section{History of the medallion}

The medallion was central to the abolitionist movement. It seems likely that it was initially intended 'for limited circulation among the Committee's corresponding members', ${ }^{9}$ but Wedgwood saw the commercial possibilities, giving many away and marketing and selling more through his company's usual channels. He personally sent medallions to prominent supporters of abolition, such as Benjamin Franklin. ${ }^{10}$ Burton has described it as 'an early version of the modern campaign badge'11 - the sort of thing we might see today worn by supporters of campaigns by Amnesty International or Oxfam.

Wedgwood may have come up with the original design on the medallion - the figure of the kneeling slave - but others soon copied him. 'Such imitations', Oldfield suggests, 'were a further indication of just how fashionable abolition had become ... [W] hat [other manufacturers] chose to copy is . . highly significant' because it is reflective of what was popular at the time. ${ }^{12}$ The figure was reproduced in a wide variety of different forms (including on crockery, in the lids of snuffboxes, or in the form of collectible token coins) over the ensuing decades. ${ }^{13}$ This led to the image quickly becoming central to the visual culture of abolition. ${ }^{14}$ By one estimate at least 200,000 medallions were produced, to say nothing of the other items carrying the same image. ${ }^{15}$ This at a time when the English population stood at under eight million.

Oldfield's conclusion is that: 'Not only did Wedgwood make abolition fashionable, he also helped to fix in the public's mind an image that would be forever associated with the abolition of slavery and the slave trade.'16 The idea that Wedgwood, through the medallion, made abolition 'fashionable' is worth noting. The medallion itself was often worn or displayed as a fashion token, a way of advertising one's personal virtue and support for the abolitionist cause. ${ }^{17}$ In the form of jewellery, the image was particularly marketed to women, during a period when conspicuous consumption was beginning to gain traction among the middle classes. ${ }^{18}$

Despite the prominence of the medallion and the image it bore, there were other images (and related art forms) used by abolitionists to promote their cause, including pictures, engravings and poetry. Oldfield argues that this art, in aggregate, propagated the idea of the 'essential goodness' of Africans, attempting to undermine the justifications for the slave trade (while, as he points out, risking the creation of alternative stereotypical images). ${ }^{19}$

\section{Two medallions}

The medallion delivered a message for the abolitionists. It conveyed a particular representation of the phenomenon that they were concerned with, concisely embodying the primary characteristics of the slave trade as they saw it. In short, the medallion portrayed a fellow human being, unjustly deprived of his freedom, to whom recognition

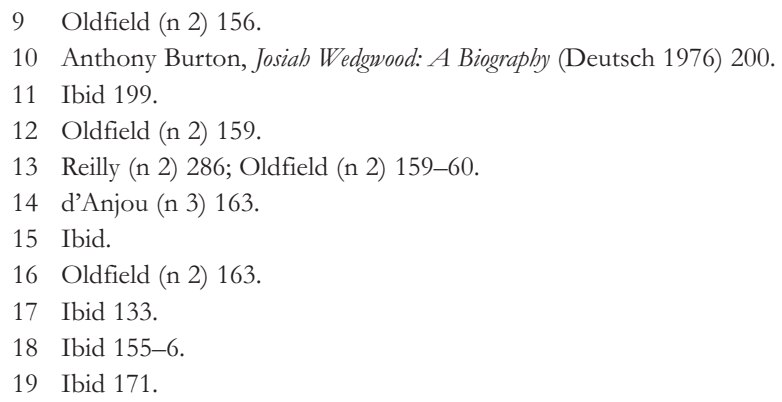


and pity ought to be extended. It argued clearly that slaves were vulnerable and passive (note the supplicatory posture) and needed the help of abolitionists. It suggested that the abolitionists' efforts were aimed at restoring to the slave the status - as a fellow human being, rather than as a commodity - of which he had been robbed. Hence the caption: 'Am I not a man and a brother?'

The medallion was a kind of 'representation technology' used by the abolitionists. As an object - and not, say, a press release or an advocacy report - the medallion is a particular kind of technology, which has certain characteristics and capacities. I find it provocative to consider the medallion as a kind of claim about a social problem because in my own work I have dealt almost exclusively with claims that come in the form of words. There may be the occasional visual image, or physical object, but these have been exceptions. My focus is not unusual; the literature on the social construction of social problems generally has followed a similar approach.

The medallion illustrates a different kind of representation, showing the possibilities of non-discursive claims about social problems. Its most obvious features are that it is small; it was designed with a particular physical role in mind (such as being worn as an ornament); it was widely distributed to a mass audience; and it was socially desirable, acting as a badge of personal virtue. It was also straightforward to understand.

The medallion's size, portability, physical function and distribution are all characteristics generally not true of discursive problem claims. And the medallion was particularly well suited to the message that the abolitionists had to convey. It is instructive that it was not the only official image sanctioned by the London Committee, but it does seem to have been by far the most successful. A second image authorised was a crosssection of a slave ship, ${ }^{20}$ revealing the awful conditions under which slaves were transported.

The medallion had two advantages over the picture of the slave ship: it was small, and therefore easy to distribute and display, and its image needed no explanation - the caption adds to its impact but was not necessary. The picture of the ship was only effective when reproduced at a reasonable size, at which scale it was not particularly portable. Its effectiveness was also more dependent on some explanation - it needed a gloss for its true impact to be realised.

When considering how the medallion functioned as a representation technology, it is useful to compare it to a contemporary anti-trafficking medallion produced by an American activist named Ken King. On 1 August 2015, King launched a crowdfunding campaign on the website Indiegogo, his objective being to raise money to cast a 'Human Trafficking Awareness medallion' for the campaign against 'Modern-Day Slavery'. His medallion has on it an image of a woman, sat on the ground, one arm covering her eyes and the other hugging her knees. The reverse of his medallion reads: 'Speak up for those who cannot speak for themselves, for the rights of all who are destitute. Speak up and judge fairly; defend the rights of the poor and needy.' This is from Proverbs 31:8-9. ${ }^{21}$

King's campaign page explicitly references the medallion under discussion here, as well as a subsequent version made by Elizabeth Margaret Chandler in the early nineteenth century.

$20<$ http://www.britishmuseum.org/research/collection_online/collection_object_details.aspx?objectId= 693429\&partId=1\&search Text=slave + ship\&page $=1>$

21 Ken King, 'Anti-Human Trafficking Medallion' (www.indiegogo.com, 8 January 2015) $<$ www.indiegogo.com/projects/anti-human-trafficking-medallion>. 
King's medallion relates to a very different context to that into which the anti-slavery medallion was introduced. Human trafficking is far more complex than slavery - at least if we understand it according to the accepted legal definition (see following section) - and as such harder to encompass in a small, easily reproducible object like the medallion. There is also no clear shared goal among the diverse anti-trafficking community. Many of the behaviours involved in trafficking are already illegal in most countries, so there is no simple legislative change to push for (such as the abolitionists pursued). It is no doubt partly for these reasons that King's medallion deals only with the trafficking of women and girls into sexual exploitation - perhaps the most common construction of trafficking in awareness-raising campaigns and media coverage. ${ }^{22}$

This kind of representation is not without risks. Those forms of trafficking that most easily lend themselves to concise, reproducible and distributable kinds of representation may come to receive a disproportionate amount of attention and funding. Correspondingly, those forms not easily represented in such ways (like trafficking for agricultural labour exploitation) may be obscured or ignored, and their victims may miss out on much needed support.

King's medallion also raises a more specific issue. The woman on his medallion is vulnerable and passive, unable even to confront the circumstances in which she finds herself. Scholars such as Julia O'Connell Davidson have argued that this kind of representation ignores the agency that many trafficked victims possess - even though their agency may be limited and without disregarding the exploitation that they suffer. ${ }^{23}$ Within the anti-trafficking community, this echoes a division between those who believe all women working in prostitution are exploited and need to be rescued, and those who believe that it is possible for sex workers to be acting autonomously, free from coercion. ${ }^{24}$

In other words, King's medallion assumes an anti-trafficking community that shares his ideas and assumptions about what trafficking involves. In fact, that community is diverse and in disagreement on some key issues. This recalls Latour's idea of the two kinds of representation that inform one another - the political and the scientific. King's medallion constitutes a kind of scientific representation insofar as it makes a claim about how the world is - but it does not do so in isolation. It represents trafficking to and for a particular community. The 'representation(s)' of that community and the 'representation(s)' of human trafficking that they draw on co-construct one another: possession and display of the medallion may signal membership in the anti-trafficking community at the same time as constituting a particular view of the issue around which that community is organised.

In the case of King's medallion, the community to which it speaks is large and diverse; the medallion captures perhaps the most prevalent representation of human trafficking

22 Erin O'Brien, for example, has argued that trafficking awareness campaigns have perpetuated an image of 'a typical or "ideal" victim of trafficking': a vulnerable, innocent women or girl who is trafficked for sexual exploitation. Erin O’Brien, 'Ideal Victims in Trafficking Awareness Campaigns' in Kerry Carrington et al (eds), Crime, Justice and Social Democracy (Palgrave Macmillan 2013) 315-16; Jo Doezema has similarly identified a prevalent trafficking 'narrative' that tends to rely on certain stereotypes regarding trafficked victims: that they are pure or virginal, that they have been deceived, and that they are subject to violence. Jo Doezema, 'Loose Women or Lost Women? The Re-emergence of the Myth of White Slavery in Contemporary Discourses of Trafficking in Women' (2000) 18 Gender Issues 23, 34-7.

23 O'Connell Davidson discusses the problem of a binary conception of 'freedom' and 'slavery' in the case of human trafficking at length in Julia O’Connell Davidson, 'Troubling Freedom: Migration, Debt, and Modern Slavery' (2013) 1 Migration Studies 176.

24 This division is discussed by Doezema (n 22) 33; see also Julia O’Connell Davidson, 'Will the Real Sex Slave Please Stand Up?' (2006) 83 Feminist Review 4, 17. 
within that community, but far from the only one. The anti-slavery medallion, by contrast, was subject to less challenge. It was more important as a signifier of community membership than King's medallion and it conveyed a representation of slavery that was dominant among the abolitionists.

\section{The medallion and political discourse}

It is useful to remember the complex of ideas and assumptions that the abolitionists chose to convey through their medallion when slavery and the slave trade are invoked in contemporary discussions of human trafficking, as both have been. To take one example, in March 2016 the Labour MP Diane Abbott said (in reference to the movement of migrants across the Mediterranean):

This people trafficking is almost the modern equivalent of the slave trade. In terms of the misery, the deaths, the profit. They're profiting in human lives. And in the end, Europe was able to deal with the slave trade, we should be able to deal with the people traffickers. ${ }^{25}$

Abbott is far from the only individual to have described trafficking as the modern equivalent of the slave trade. In the bicentennial celebrations of the abolition of the slave trade, in 2007, the British government used the occasion in part to advertise its efforts to combat trafficking. Prime Minister Tony Blair, in a speech to mark the occasion, referred to various modern forms of slavery, among which he included human trafficking. ${ }^{26}$ Nor is every such comparison or invocation made explicit. On 23 March 2007, when the British government signed the Council of Europe Convention on Action against Trafficking in Human Beings, Home Secretary John Reid did the physical signing of the document on the desk that had once belonged to William Wilberforce, noted abolitionist campaigner. ${ }^{27}$

To describe trafficking as somehow equivalent to the slave trade is, broadly speaking, misleading. While the exact definition of trafficking remains somewhat contentious, the most authoritative definition has not changed since it was introduced in 2000 in the UN 'Palermo' Protocol. ${ }^{28}$ That definition has three parts: movement, means and purpose. Movement refers not just to transporting someone, but also recruiting or receiving them. Means refers to force or deception. Purpose refers to exploitation, broadly defined. So the act of trafficking comprises moving someone, by force or by deception, with the intent to exploit them.

The slave trade was a much more specific phenomenon than this: it typically involved individuals who were physically taken from their homes, transported in chains, and forced to work on penalty of violence or death under severely exploitative conditions (though this is necessarily a partial generalisation). Human trafficking can involve similar

25 Daniel Bond, 'Diane Abbott: "People Trafficking is the Modern Equivalent of the Slave Trade. We Have to End It" (Politics Home 3 March 2016) <www.politicshome.com/news/uk/politics/house/73030/dianeabbott-people-trafficking-modern-equivalent-slave-trade-we-have $>$.

26 'Slave Trade Shameful, Blair Says' BBC News (25 March 2007) <http://news.bbc.co.uk/1/hi/uk/6493507.stm>.

27 'Home Secretary Signs Vital Anti-Trafficking Convention' (Home Office 17 April 2008) <http://web.archive.org/web/20080417013110/http://www.homeoffice.gov.uk/aboutus/news/convention-against-trafficking $>$.

28 'Protocol to Prevent, Suppress and Punish Trafficking in Persons, Especially Women and Children, Supplementing the United Nations Convention against Transnational Organized Crime' (signed 15 November 2000, entered into force 25 December 2003) 2237 UNTS 319. 
situations, but encompasses a far broader range of behaviours. The kinds of exploitation to which a trafficked victim may be subject include forced street begging, domestic servitude, cannabis cultivation, agricultural labour and sexual exploitation (among others). The degree of exploitation in any given case will vary from more to less severe. It is only a subset of trafficking cases that can be said to bear any resemblance to the slave trade. Often, trafficked victims are deceived into travelling (rather than being kidnapped), may be subject to psychological coercion (rather than physical imprisonment) and may even receive some payment.

This is not to downplay the gravity of the crime of trafficking, or the frequently horrendous conditions to which its victims are exposed. But we must be able to make descriptive distinctions between different kinds of criminal behaviour and mistreatment if we are to design effective responses to them, rather than risk trying to tackle a range of disparate problems with a single approach. The invocation of the slave trade risks occluding these nuances.

Yet, the use of the terms 'slavery' and 'slave trade' in discussions of trafficking can be difficult to challenge. Partly, that is because to do so risks seeming to trivialise the suffering to which trafficked victims are subject. Partly it is because it is not completely clear how 'slavery' and 'the slave trade' are being used in comments such as Abbott's quoted remark: 'This people trafficking is almost the modern equivalent of the slave trade'. ${ }^{29}$ Does that mean that trafficking is similar to the slave trade? That it is different but in some way the successor to the slave trade? Is 'the slave trade' being invoked symbolically to convey the severity of the experiences of trafficked victims? Or metaphorically, perhaps intended to highlight the lack of freedom of people who are trafficked?

This ambiguity is revealing if we think of the examples $I$ have given as representational technologies distinguished by their use of language - we can label them discursive technologies (press conferences, interviews, pronouncements). We might think that discursive representational technologies would be more explicit and specific than material technologies such as the medallion. In fact, they may be less so.

The medallion can speak a kind of truth to these contemporary, discursive representations, grounding them and forcing them to resolve their ambiguity. This is because the medallion is not just the image of the kneeling slave; it is also the object on (and into) which that image is set. It is both the image and the medallion that carries it it combines the two. It anchors the idea of slavery - and of abolition - to a particular historical context, grounded in a process of design and manufacture, directed by identifiable individuals for specific purposes. Rather than a loose rhetorical exercise, calling on vaguely specified assumptions and associations, we are compelled to say: here is what the slave trade meant to these people at this time, and here, consequently, is its precise relation to human trafficking.

In the presence of the medallion, symbolic or metaphorical uses of the 'slave trade' in discussions of trafficking are constrained. The only viable usage becomes the comparison - a listing of similarities and differences between two recognisably discrete phenomena. As a comparison, the slave trade can be instructive; as a looser metaphor or category, it is dangerous. 


\section{The materiality of the law}

The idea that material representation technologies can sometimes be more explicit than non-material kinds sheds interesting light on the most recent anti-trafficking intervention in the UK - the passage of the Modern Slavery Act 2015. ${ }^{30}$ A piece of legislation is also (though not just) a representation technology - a way of conveying a particular understanding of an issue. The Modern Slavery Act attempted to reconceptualise 'human trafficking' in terms of 'modern slavery', shifting the general thrust of anti-trafficking efforts towards a focus on more extreme forms of exploitation where movement was a less significant factor. It built on a growing desire by the British government to devote resources to a narrower range of kinds of trafficking in which particularly severe mistreatment was occurring - such as cases where individuals have been physically imprisoned for considerable amounts of time. ${ }^{31}$

However, the Act largely reproduced offences (of human trafficking and of slavery, servitude and forced labour) that already existed in earlier legislation. ${ }^{32}$ This is counterintuitive; the most straightforward way to redefine a criminal issue such as trafficking would be to rewrite the relevant criminal offences. The Act did introduce some new provisions, but these did not significantly modify the way in which trafficking was constructed.

If, then, we pay attention only to the text of the Act, treating it as immaterial, as a set of abstract rules and categories, it seems underwhelming. It gives the impression of being a simple rebranding exercise - existing offences are repackaged with a few minor additional provisions, allowing the government to claim it is taking action. In fact, the legislation was more substantively important than this impression might suggest. But in order to see that, we have to look beyond the text of the Act's provisions, considering also its material, non-discursive aspects. We can do so by looking in two principal directions: para-text and con-text.

By 'para-text', I mean to refer to non-textual features of the Act itself. A piece of legislation is more than the words on the page. It also has a physical existence; it has a specific layout and typography. The Modern Slavery Act had two main features outside of its core provisions that constitute an important aspect of the Act's representation of trafficking. First, and most straightforwardly, is the title: the term 'modern slavery' here replaces 'human trafficking' as the ordering concept and umbrella term (human trafficking had previously been the umbrella concept, with slavery treated as a subordinate category). Second, the ordering of offences is important. Section 1 is the offence of slavery, servitude and forced labour; section 2 is the human trafficking offence. This reverses the chronological order in which the offences were introduced and lends prominence to the first offence over the second. Trafficking was implicitly presented as a subcategory of 'modern slavery'.

The other non-textual feature of the Act is its 'con-text', by which I mean the other texts with which the legislation relates. The Act informs how we read them, as they inform how we read the Act. Again, I see this as a material dimension to the legislation - going

30 Modern Slavery Act 2015.

31 Interview with an NGO participant conducted during my doctoral fieldwork.

32 Sexual Offences Act 2003, ss 57-9; Asylum and Immigration (Treatment of Claimants, etc.) Act 2004, s 4; Coroners and Justice Act 2009, s 71. The offence of slavery, servitude and forced labour was introduced in 2009 in recognition of a gap in the existing trafficking offences. Those offences did not allow for the criminalisation of acts of exploitation where no movement was present. Hence, the 2009 offence was seen as part of human trafficking law and reproduced as such in subsequent publications. 
beyond the text of its provisions. For example, the Home Office published a Modern Slavery Strategy in 2014, to coincide with the preparation of the Act. The strategy claimed that slavery still existed in the UK. ${ }^{33}$ Similarly, the Explanatory Notes published alongside the Act implicitly framed trafficking as a subcategory of 'modern slavery'. ${ }^{34}$

As a representation of trafficking, the Modern Slavery Act only reveals its true significance - and its workings - when considered not just as a set of rules and definitions but also as a material object. I was prompted to consider those aspects of the Act by thinking about the medallion - and about the varied forms that problem representations can take. Deprived of its materiality, the Modern Slavery Act is confusing; it does not seem to do very much. But given its materiality, placed into its particular context, it reveals a narrative that will no doubt have significant consequences for future anti-trafficking work in the UK.

\section{Conclusions}

Materiality is a strange thing to overlook. I carried out fieldwork for my doctoral research, interviewing real people in real places, handling paper files, attending events with buffet lunches, posters and air-conditioned presentation rooms. Yet, very little of that is present in my analysis. The tangible experience that I gathered from my fieldwork has been reduced to words - both in the sense that words are what I use to describe it and, more insidiously perhaps, in that words are (mostly) what I describe.

Occasional objects make an appearance - the desk that belonged to William Wilberforce, now kept in the Home Office building; the videoconferencing equipment used in a trial I observed; the clothing sourced for trafficked victims so they would have something to wear after they were rescued and taken into sheltered accommodation. But these are, for the most part, decorative, in the sense that they do not form a core component of my analysis. And there is no visual aspect to the presentation of that analysis. In fact, the manner of presentation that I have used is carefully governed by various sets of typographical guidelines - those dictating how a doctoral thesis must be formatted, those setting out requirements for submission to a particular journal. (It is perhaps interesting to reflect on the detailed guidance for footnote formatting that we all have to conform to, and the relative absence of guidance on including images, video, or material artefacts in our work.)

Part of the reason that words are so central to my work is that they form the majority of what we can easily see when we look at the workings of government. There are material dimensions to those words that can be hard to access. In my research, for example, I discuss certain 'pots' of government money - excess funds, planned spending, money running out. But I do this based on words - from interviews and published documents. I could not get directly at the things that money purchased, at the flow of cash between bank accounts, or even at receipts and expense claims, all of which lay behind the words that I found.

In this context it may perhaps be indicative that the etymology of the verb 'to publish' lies originally in the Latin publicare - to make public. Latour argues that "parliament" is a technical term for "making things public". 35 He treats parliament as only one "among

33 Home Office, Modern Slavery Strategy (HM Government 2014) 5.

34 'Explanatory Notes to the Modern Slavery Act 2015' (2015).

35 Latour (n 6) 24. 
many other forms of producing voices and connections among people', but since my focus is on the British state it is useful here to take him at his word. ${ }^{36}$

When an institution like the state publishes certain documents, it is deciding what to make public, visible and accessible. It is not simply a question of which documents are published and which are not; it is also a question of what is put into documentary form at all - and what is left, perhaps, in the material realm, unarticulated.

By excavating the material dimensions of the state and its (often discursive) representational technologies, it may be possible to articulate some of what remains unsaid in the activities of governments and parliaments, which is, perhaps, one additional argument for the use of modelling and materiality in research. I hope that my future work will bear witness to that. 
